\title{
Modeling Study and Performance Investigation of a Thermoelectric Refrigerator
}

\author{
Haydar Kepekçi ${ }^{1 *}$, Ergin Kosa ${ }^{2}$, Cüneyt Ezgi ${ }^{3}$
}

\begin{abstract}
Thermoelectric refrigerators are widely used in electronics, medical, and food industry application areas. A refrigeration effect can also be achieved without using any moving parts by merely passing a small current through a closed circuit made up of two dissimilar materials. This effect is called the Peltier effect, and a refrigerator that works on this principle is called a thermoelectric refrigerator. They consist of several thermoelectric legs sandwiched between two thermally conductive plates, one cold and one hot. Thermoelectric refrigerators presently cannot compete with the vapor-compression refrigeration system because of their low- coefficient of performance (COP). However, some applications have been preferred because of their small size, simplicity, quietness, and reliability. In this study, a thermoelectric cooler having a maximum cooling power of $50 \mathrm{~W}$, having a dimension of $40 \mathrm{mmx} 40 \mathrm{mmx} 3.6 \mathrm{~mm}$, is modeled in multi-physics software. Also, the performance of a thermoelectric refrigerator is investigated. It is computed the temperature difference between ceramics plates versus electric current and COP for a temperature difference between ceramics plates. The simulation results are compared with experimental data. The data obtained from the analyses have been compared with the experimental results and found to agree with each other. For the surface temperatures of $25^{\circ} \mathrm{C}$ and $50^{\circ} \mathrm{C}$, the maximum coefficients of performance have been computed to be 1.091 and 1.445 , respectively. In general, as the temperature of hot surfaces has increased for the same temperature differences, the COP of the thermoelectric cooler has increased.
\end{abstract}

Keywords: Thermoelectric, COP, refrigerator, CFD, modeling

\section{Termoelektrik Soğutucunun Modelleme Çalışması ve Performans İncelemesi}

\section{ÖZ}

Termoelektrik soğutucular elektronik, medikal ve gıda endüstrisi uygulama alanlarında yaygın olarak kullanılmaktadır. İki farklı malzemeden oluşan kapalı bir devreden sadece küçük bir akım geçirerek herhangi bir hareketli parça kullanmadan da bir soğutma etkisi elde edilebilir. Bu etkiye Peltier etkisi, bu prensibe göre çalışan soğutucuya ise termoelektrik soğutucu denir. Bu sistemler, biri soğuk diğeri sıcak iki termal iletken plaka arasına sıkıştırılmış birkaç termoelektrik bacaktan oluşurlar. Termoelektrik soğutucular, düşük performans katsayıları (COP) nedeniyle şu anda buhar sıkıştırmalı soğutma sistemleri ile rekabet edememektedir. Ancak bazı uygulamalarda küçük boyutları, sadeliği, sessizliği ve güvenilirliği nedeniyle tercih edilmişlerdir. Bu çalışmada, maksimum soğutma gücü $50 \mathrm{~W}$ olan, $40 \mathrm{mmx} 40 \mathrm{mmx} 3.6 \mathrm{~mm}$ boyutlarında bir termoelektrik soğutucu hesaplamalı akışkanlar dinamiği programı kullanılarak modellenmiştir. Ayrıca, bir termoelektrik soğutucunun performansı araştırılmıştır. Yapılan hesaplamalarda seramik plakalar arasındaki sıcaklık farkı ve elektrik akım hesapları yapılmıştır. Ayrıca simülasyondan elde edilen sonuçlar deneysel verilerle karşılaştırılmıştır. Analizlerden elde edilen veriler deneysel sonuçlarla karşıllaştırılmış ve birbiriyle uyumlu olduğu görülmüştür. $25^{\circ} \mathrm{C}$ ve $50^{\circ} \mathrm{C}$ yüzey sıcaklıkları için maksimum performans katsayıları sırasıyla 1.091 ve 1.445 olarak hesaplanmıştır. Genel olarak, aynı sıcaklık farkları için sıcak yüzeylerin sıcaklığı arttıkça termoelektrik soğutucunun COP değeri artmıştır.

Anahtar Kelimeler: Termoelektrik, COP, soğutucu, HAD, modelleme

\footnotetext{
" Iletişim Yazarı

Geliș/Received

21.06 .2021

Kabul/Accepted

12.08.2021

1 Nişantaşı University, Engineering Faculty, Mechatronic Engineering Department, İstanbul haydar.kepekci@nisantasi.edu.tr, ORCID: 0000-0002-0037-8332

2 Beykent University, Engineering Faculty, Mechanical Engineering Department, İstanbul, erginkosa@beykent.edu.tr ORCID: 0000-0002-4607-4115

3 Piri Reis University, Engineering Faculty, Marine Engineering Department, İstanbul, cezgi@pirireis.edu.tr ORCID: 0000-0003-3264-0021
} 


\section{INTRODUCTION}

Thermoelectric systems were initially examined about 70 years ago, and the use of these devices for air-conditioning and cooling implementations was evaluated shortly later [1]. For years, thermoelectric trading modules have been present, and their price has reduced over time. With researchers' work, thermoelectric devices convert heat energy into electrical energy in the form of a temperature gradient or convert electrical power into a temperature gradient [2]. The thermoelectric modulus technic is the best economic remedy for causes. The thermoelectric modules are usual off-the-shelf parts, the relevance of their running voltages to series-parallel electrical circuitry, simple montage, and small size [3]. A thermoelectric cooler is a little heat pump that has the benefit that there are no moving components.

Thermoelectric modules are mini, lightweight, and can provide cooling below atmospheric temperature. Thermoelectric systems are environmentally friendly as they do not use any refrigerant during operation [2]. The positive aspects of these devices are; reliability, quiet operation, and compactness. As a result, it has attracted many researchers' attention in terms of developing and expanding thermoelectric systems. Furthermore, various reports have demonstrated the feasibility of using thermoelectric modules as a promising alternative for conventional air cooling and heating systems [4]. One reason why thermoelectric cooling systems can be widely used in electronic devices is; temperature control capacity is to provide an efficient heat transfer. It also offers advantages such as high reliability and fast thermal response [5].

The thermoelectric modulus supplies heat transfer through alteration in the energy level of the electrons. The current low energy level P-type semiconductors and high energy level N-type semiconductors transport the heat energy from the cold surface to the hot surface [6]. Another name for thermoelectric refrigerants is Peltier. The Peltier module is created by the serial link of P-type and N-type elements. The Peltier impact happens with the direct current by the Peltier components. In this process, one surface of the thermoelectric modulus cools while the other surface heats [7]. The Peltier module is shown in Fig. 1.

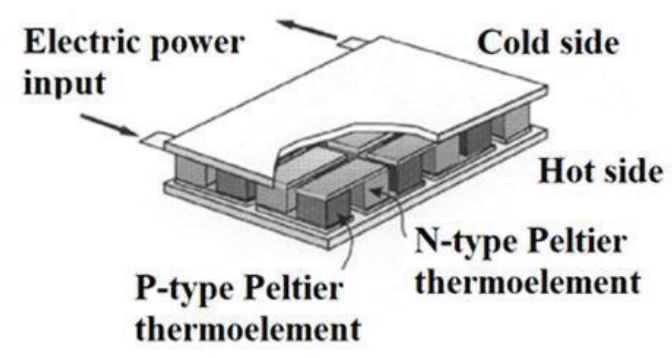

Figure 1. Thermoelectric CoolerProfili 
In the system shown in Fig. 1, heat is absorbed from the refrigerated space and rejected to the warmer environment. The difference between these two quantities is the net electrical work that needs to be supplied. For the Peltier cooling systems to work correctly, the module's hot side needs to be cooled. Therefore, when designing thermoelectric cooling systems, a cooling component such as a fan should be added. Thermoelectric refrigeration based on the Peltier impact has significant benefits check against traditional vapor technology, although its COP is not as high a vapor-compression technology. Today, thermoelectric cooling's practice fields contain thermoelectric refrigeration, automobile cooling, thermoelectric air-conditioning, photovoltaicthermoelectric hybrid system, and freshwater production [8].

Tan and Zhao [9] studied a thermoelectric system for air conditioning with the combination of a phase transition matter as an option to the refrigerant. The addition of phase changer matter led to a $56 \%$ increase in thermoelectric module performance. Dessel and Messac [10] experimentally analyzed the thermoelectric performance as an air conditioning system with the combination of the PV system for the procurement of electricity with different electrical connections, input current, and other voltage values. Experimental results demonstrated that the input current alteration does not influence the temperature of the cold surface, but rather the temperature of the hot surface is much influenced. They decided that the cold side's temperature achieves steady-state and stability circumstances faster than the hot surface.

Chinguwa et al. [11] designed an environmentally friendly in-car cooler. They used a thermoelectric cooler in the portable design of 20 liters. As a result of their work, they have significantly reduced exhaust gas to the environment. Tan and Demirel [6] conducted an experimental study using three different cooling systems to examine the temperature and performance of the CPU and the motherboard. The systems used are; heat sink, water cooling system, and thermoelectric cooler. Their results found that the thermoelectric cooling system had better cooling performance than the other two systems under continuous operating conditions. Huang et al. [12] devised a new style procedure for thermoelectric cooler systems in that an experimentally created performance curve of the thermoelectric module was done for design computation. Furthermore, automated testing furnishing was devised and made to take the test. Considering the performance test outcomes, an empiric correlation was obtained for Peltier module performance, and the sequel was used in the system research of a thermoelectric cooler.

Karimi et al. [13] analyzed a pyramid-type multi-stage cooling focusing on the significance of the highest achievable target heat flux and performance coefficient. As a result of the study carried out as numerical simulation, the hot side heat sink's thermal resistance, a multi-stage thermoelectric cooler, has a crucial role in determining all performance. Riffat et al. [1] developed a computer model to measure the perfor- 
mance of a thermoelectric heat pump system. They compared the numerical results with experimental data. They analyzed the reasons for the differences and optimized the computer model. Their work was the basis for analyzing and designing the thermoelectric heat pump system. Gökçek and Sahin [8] performed an experimental performance analysis of a mini channel water-cooled thermoelectric refrigerator. The cooling system of the fridge used in the experiment; consists of the mini-channel heat sink on the hot side and two thermoelectric modules integrated with heat distributors on the cold side. As a result, they concluded that the mini-channel heat sink's performance was as good as other liquid-cooled systems.

Nagy and Buist [14] analyzed a thermoelectric cooler's performance and indicated a critical performance decrease due to the thermal resistance of heat sinks. They concluded that the thermal resistance of the heat sinks and the thermal interfaces among the modulus and the heat sinks should be reduced to reach the best feasible refrigerating performance.

The primary purpose of the thermoelectric refrigerator research was to investigate the cooling performance. The coefficient of performance (COP) for the refrigerator is accepted as the performance criterion. This value is the ratio between the cooling load and electrical power consumption. Refrigerators' performance is expressed in terms of the COP as ratio work input of the cooling effect. A prototype cooler with the same characteristics has been designed, and experimental work has been done. The data obtained from the numerical analysis and the data obtained from the experiments have been compared.

\section{EXPERIMENTAL METHOD}

As shown in Fig. 2, the experimental equipment is installed in a controlled volume. For the Peltier cooler to work well, one above the thermoelectric cooler module and the other above the closed box, two cooling fans' control volume, two cooling fans, and two heat sinks are used. The thermoelectric cooler's underside is designed as a cold area in the prototype system, and appropriate insulation is made. The dimensions of the rectangular covering are selected as $500 \mathrm{~mm}$ x $500 \mathrm{~mm}$ x $250 \mathrm{~mm}$. Insulation has been provided by using approximately $50 \mathrm{~mm}$ thickness Styrofoam on the cooling side. The size of the cooling side is $215 \mathrm{~mm} \times 175 \mathrm{~mm} \times 130 \mathrm{~mm}$.

The installation also contains the electronic components necessary for the operation of the system. The model of the thermoelectric cooler used has been chosen as TEC112706. The " 127 " indicates each one $127 \mathrm{n}$ and $\mathrm{p}$ type semiconductor pairs while the " 06 " correspond to their maximum current (6 amp). The dimensions of the thermoelectric cooler module used in the system shown in Fig. 3 are 40x40x3.6 mm. The specification of the TEC1-12706 conditions is provided in Table 1. 

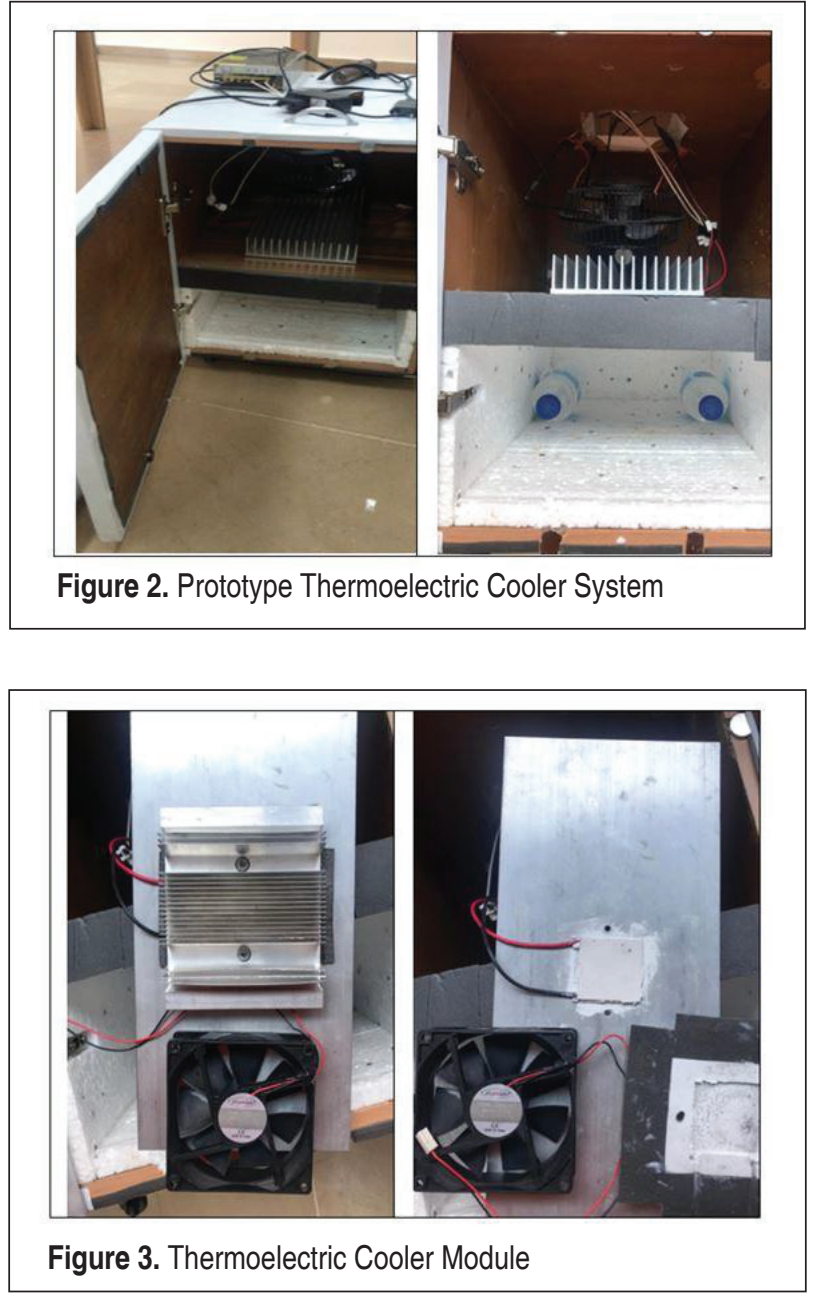

Table 1. Performance Specifications of TEC1-12706

\begin{tabular}{|c|c|c|}
\hline Hot Side Temperature $\left[{ }^{\circ} \mathrm{C}\right]$ & 25 & 50 \\
\hline $\mathbf{Q}_{\max }[\mathrm{W}]$ & 50 & 57 \\
\hline$\Delta \mathrm{T}_{\max }\left[{ }^{\circ} \mathrm{C}\right]$ & 66 & 75 \\
\hline $\mathrm{I}_{\max }[\mathrm{A}]$ & 6.4 & 6.4 \\
\hline $\mathrm{V}_{\max }[\mathrm{V}]$ & 14.4 & 16.4 \\
\hline Module Resistance $[\Omega]$ & 1.98 & 2.30 \\
\hline
\end{tabular}


Table 2. Physical Properties Of The Devices Used

\begin{tabular}{|l|c|c|}
\hline Device Type & Range & Sensitivity \\
\hline Thermometer & $-50\left[{ }^{\circ} \mathrm{C}\right]-300\left[{ }^{\circ} \mathrm{C}\right]$ & $1\left[{ }^{\circ} \mathrm{C}\right]$ \\
\hline Voltmeter & $0.1[\mathrm{mV}]-600[\mathrm{~V}]$ & $\% 0.5+3$ \\
\hline Ohmmeter & $0.1[\Omega]-40[\mathrm{M} \Omega]$ & $\% 0.5+2$ \\
\hline Ammeter & $0.1[\mathrm{~A}]-400[\mathrm{~A}]$ & $\% 1.5+3$ \\
\hline
\end{tabular}

All temperatures have been measured using thermocouples with a sensitivity of \pm 1 C. Type E has been chosen as the type of thermocouple conductor. In this system, the ammeter has used for current measurement; the voltmeter has used for voltage measurement; the ohmmeter has used for resistance measurement. The operating range and sensitivity of the measuring devices used are given in Table 2.

Cooling fins (heat sink) are fabricated of aluminum and attached to the thermoelectric refrigerator's surfaces to reduce their operating temperatures. Small fans are used to induce forced convection over the fins. A temperature drop of $10 \mathrm{oC}$ in one hour has been observed in the water in 2 plastic bottles of 0,5 -liter water $\left(\mathrm{Q}=\mathrm{m} . \mathrm{c} \_\mathrm{p} . \Delta \mathrm{T}\right)$. For this reason, it has been concluded that one thermocouple was sufficient for the cooled volume.

\section{SIMULATION METHOD}

A simulation methodology has been examined on a thermoelectric cooler with the parameters used in the experimental study. After the computations are completed, the results are compared with experimental data.

The 3D mesh domain image of the thermoelectric cooler analyzed is, as shown in Fig. 4. This mesh has contained about 170,000 cells.

The mesh file's size parameters have been selected as follows; the maximum element

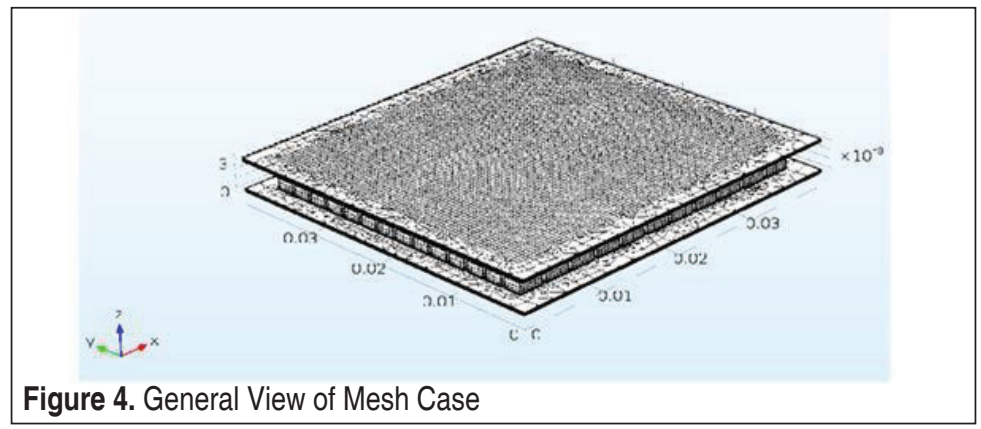


Table 3. Properties of Bismuth Tin

\begin{tabular}{|l|c|}
\hline Property & Expression \\
\hline Specific heat capacity $\left(c_{\mathrm{p}}\right)$ & $171.6588[\mathrm{~J} /(\mathrm{kg} . \mathrm{K})]$ \\
\hline Density $(\rho)$ & $8340\left[\mathrm{~kg} / \mathrm{m}^{3}\right]$ \\
\hline Seebeck coefficient $(\alpha)$ & $-55 \times 10^{-6}[\mathrm{~V} / \mathrm{K}]$ \\
\hline Electrical conductivity $(\sigma)$ & $6.0976 \times 10^{4}[\mathrm{~S} / \mathrm{m}]$ \\
\hline Thermal conductivity $(\mathrm{k})$ & $24.5[\mathrm{~W} /(\mathrm{m} . \mathrm{K})]$ \\
\hline Relative permittivity $(\xi)$ & 1 \\
\hline
\end{tabular}

size is $2 \times 10^{-4}$, the minimum element size is $2 \times 10^{-6}$, the maximum element growth rate is 1.3 , curvature factor is 0.2 , resolution of narrow regions is 1 . The geometry and their mesh have been created using computational fluid dynamics software.

The material of the P-Type and N-Type semiconductor elements of the thermoelectric cooler is Bismuth Tin, the conductor material is copper, and the ceramic material is Tungsten.

The meshes are structured inside of the geometry. The purpose of the analysis is to measure the coefficient of performance values at different currents. As current values, 1.5 A, $3 \mathrm{~A}, 4.5 \mathrm{~A}$, and $6 \mathrm{~A}$ have been selected. Analyzes have been performed for both $25{ }^{\circ} \mathrm{C}$ and $50{ }^{\circ} \mathrm{C}$.

SNOPT has been chosen as the solver method. SNOPT is a specific application, which is making use of a semidefinite quadratic programming solver. It is based on a finite-memory quasi-Newton approach to the Hessian of the Lagrangian and uses a Reduced-Hessian algorithm (SQOPT) for resolving the quadratic programming subproblems. It is designed for many thousands of limitations and factors but an average number of degrees of freedom [15]. In the analysis, a PC with "Intel (R) Core (TM) i7-4710HQ CPU@2.50GHz, four cores” has been used. This computational time was approximately 20 minutes.

\section{RESULTS}

As a result of the analysis for the surface temperature of $25^{\circ} \mathrm{C}$, the maximum temperature difference has been calculated to be $21.150 \mathrm{~K}$. The current required to obtain this value is $6 \mathrm{~A}$. The required voltage is $0.44423 \mathrm{~V}$. The overall electrical resistance is $0.074038 \Omega$. The maximum heat dissipation is $12.285 \mathrm{~W}$; the maximum coefficient of performance is 1.091 .

The figure for merit is $0.00239451 / \mathrm{K}$. As can be seen from Fig. 5, the surface tempe- 


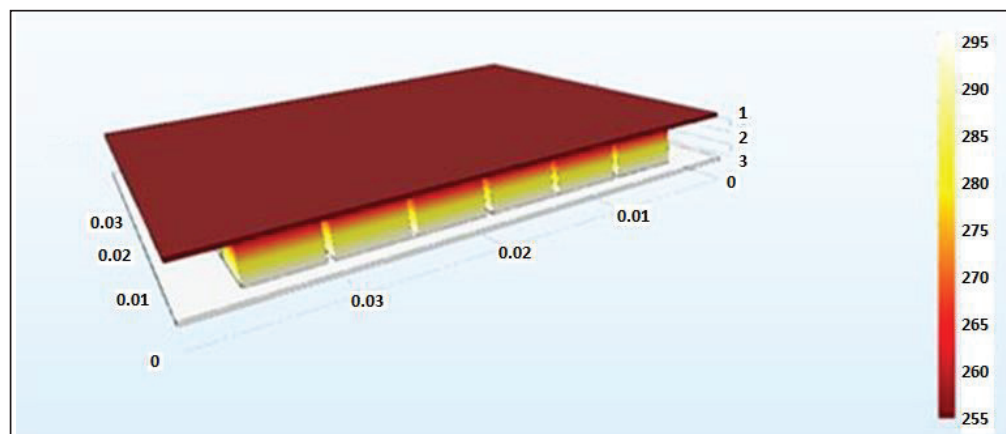

Figure 5. Surface Temperature for $\mathrm{T}_{\mathrm{h}}=25^{\circ} \mathrm{C}$

rature of the hot side goes up to $255 \mathrm{~K}$, and at combining points, the temperature can be up to $295 \mathrm{~K}$.

The temperature difference of the thermoelectric cooler has increased as the current has increased. The change of I (A) versus $\Delta \mathrm{T}(\mathrm{K})$ for $\mathrm{Th}=25^{\circ} \mathrm{C}$ is illustrated in Fig. 6.

The temperature difference of the thermoelectric cooler has reduced as the cooling load has increased. The change of cooling load versus $\Delta \mathrm{T}(\mathrm{K})$ for $\mathrm{Th}=25^{\circ} \mathrm{C}$ is illustrated in Fig. 7.

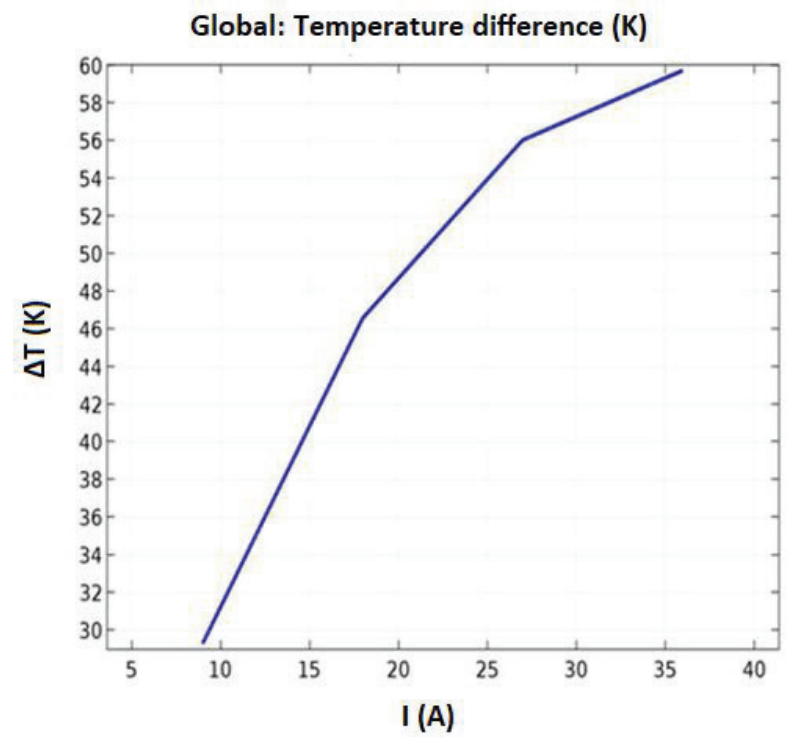

Figure 6. The change of I (A) versus $\Delta T(K)$ for $T_{h}=25^{\circ} \mathrm{C}$ 

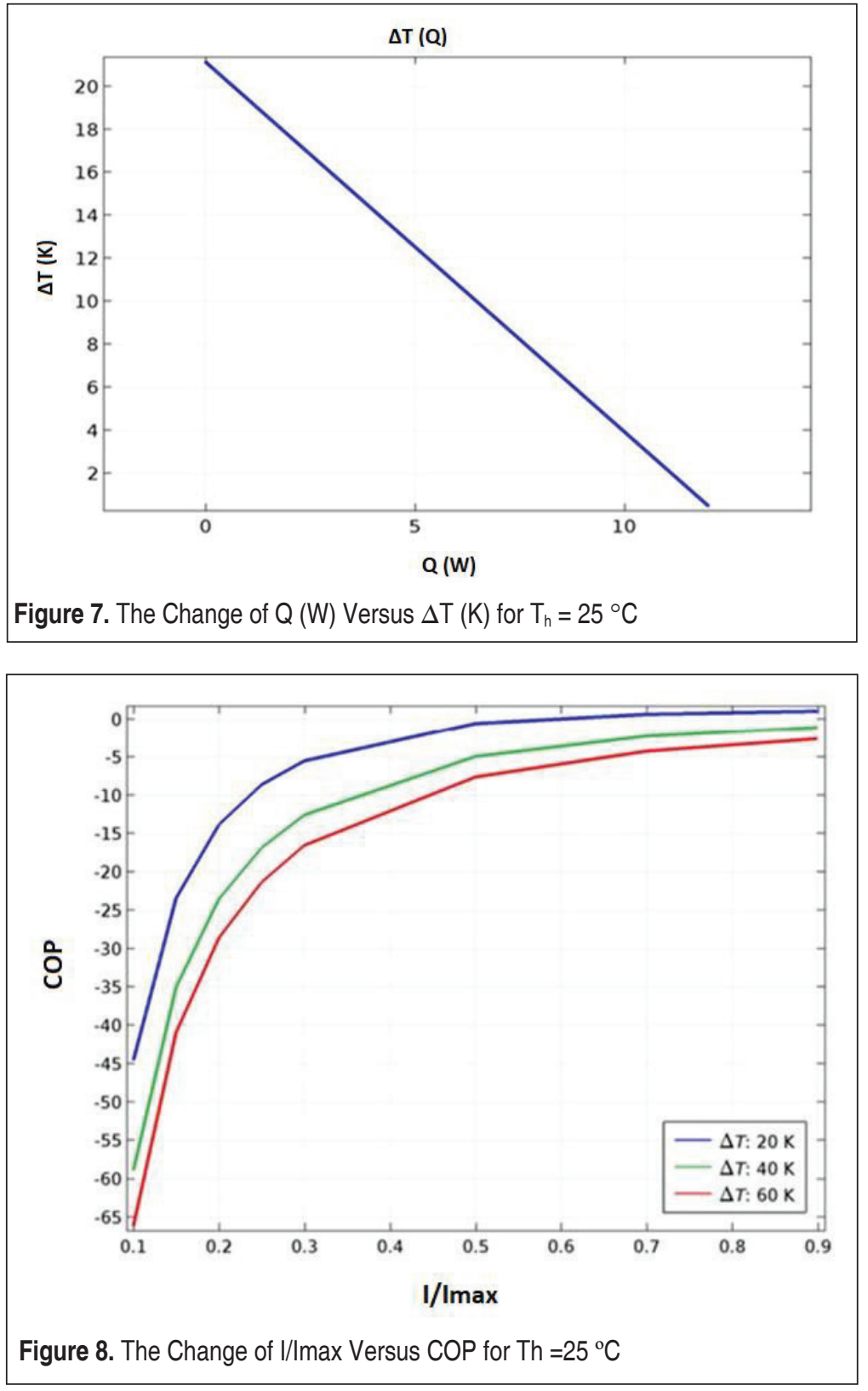

For temperature differences between ceramics plates of $20 \mathrm{~K}, 40 \mathrm{~K}$, and $60 \mathrm{~K}$, the change of COP versus the relative applied current I/Imax, from 0.1 to 0.9 , is depicted in Fig. 8. 


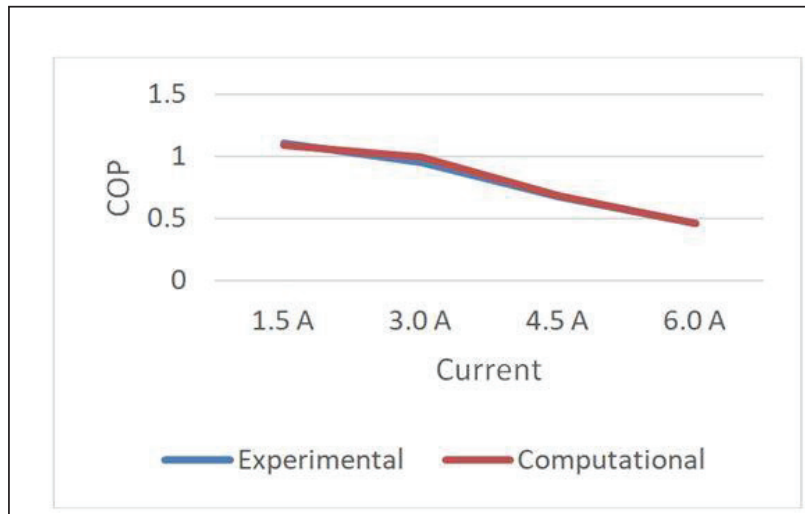

Figure 9. Current-dependent COP for $T_{h}=25^{\circ} \mathrm{C}$ and $\Delta T=20 \mathrm{~K}$
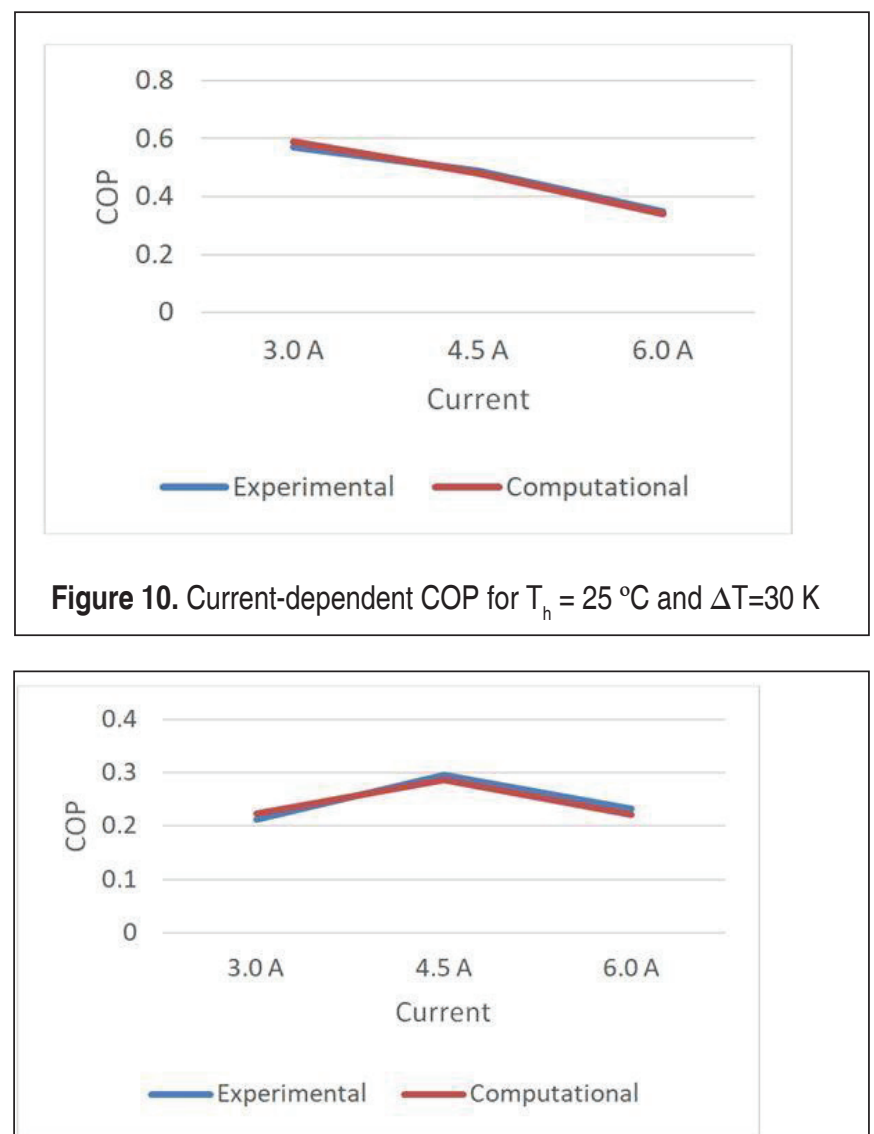

Figure 11. Current-dependent COP for $T_{h}=25^{\circ} \mathrm{C}$ and $\Delta T=40 \mathrm{~K}$ 


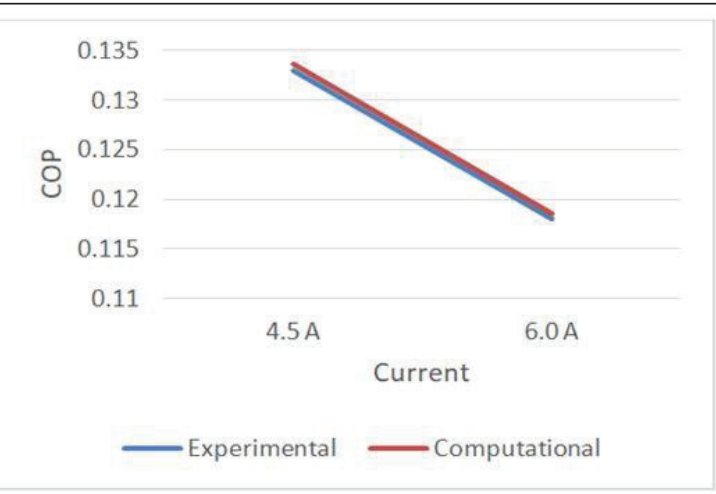

Figure 12. Current-Dependent COP for $\mathrm{T}_{\mathrm{h}}=25^{\circ} \mathrm{C}$ and $\Delta \mathrm{T}=50 \mathrm{~K}$

In Fig. 9, Fig. 10, Fig. 11, and Fig. 12; $\mathrm{Th}=25^{\circ} \mathrm{C}$; COP coefficients at different current for each $\Delta \mathrm{T}$ value are given both experimentally and numerically. As the current has increased, the COP of the thermoelectric cooler has reduced. As indicated in Fig. 9, it can be said that numerical results are in good agreement with experimental data. The reason for the uncertainties in the calculated values is the $\pm 1 \mathrm{C}$ margin of error of the E-type thermocouple used.

Since the thermoelectric cooler's cooling load is zero at $3 \mathrm{~A}$ in $\mathrm{T}_{\mathrm{h}}=25^{\circ} \mathrm{C}$ and $\Delta \mathrm{T}=50$ $\mathrm{K}$, it is not considered in Fig. 12.

As a result of the analysis for the surface temperature of $50^{\circ} \mathrm{C}$, the maximum temperature difference has been calculated to be $24.496 \mathrm{~K}$. The current required to obtain this value is $6 \mathrm{~A}$. The required voltage is $0.50462 \mathrm{~V}$. The overall electrical resistance is $0.084103 \Omega$. The maximum heat dissipation is $13.844 \mathrm{~W}$; the maximum coefficient of performance is 1.445 . The figure for merit is $0.00237671 / \mathrm{K}$. The hot side's surface temperature goes up to $265 \mathrm{~K}$. Surface Temperature for $\mathrm{Th}=50^{\circ} \mathrm{C}$ is shown in Fig. 13.

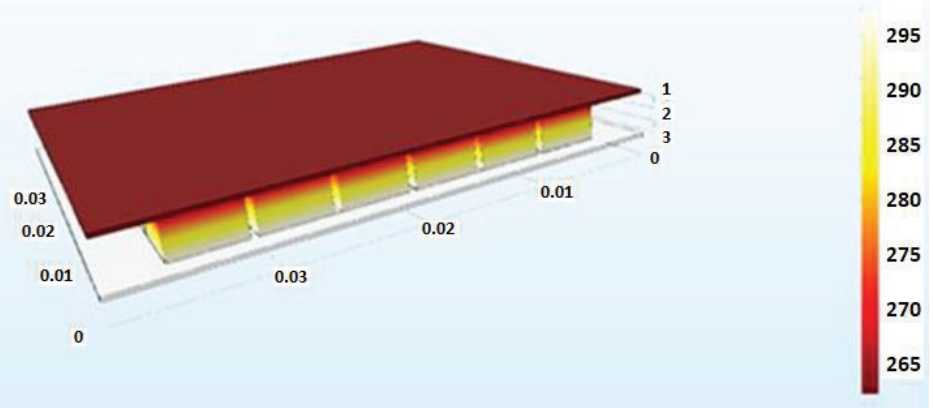

Figure 13. Surface Temperature for $T_{h}=50^{\circ} \mathrm{C}$ 


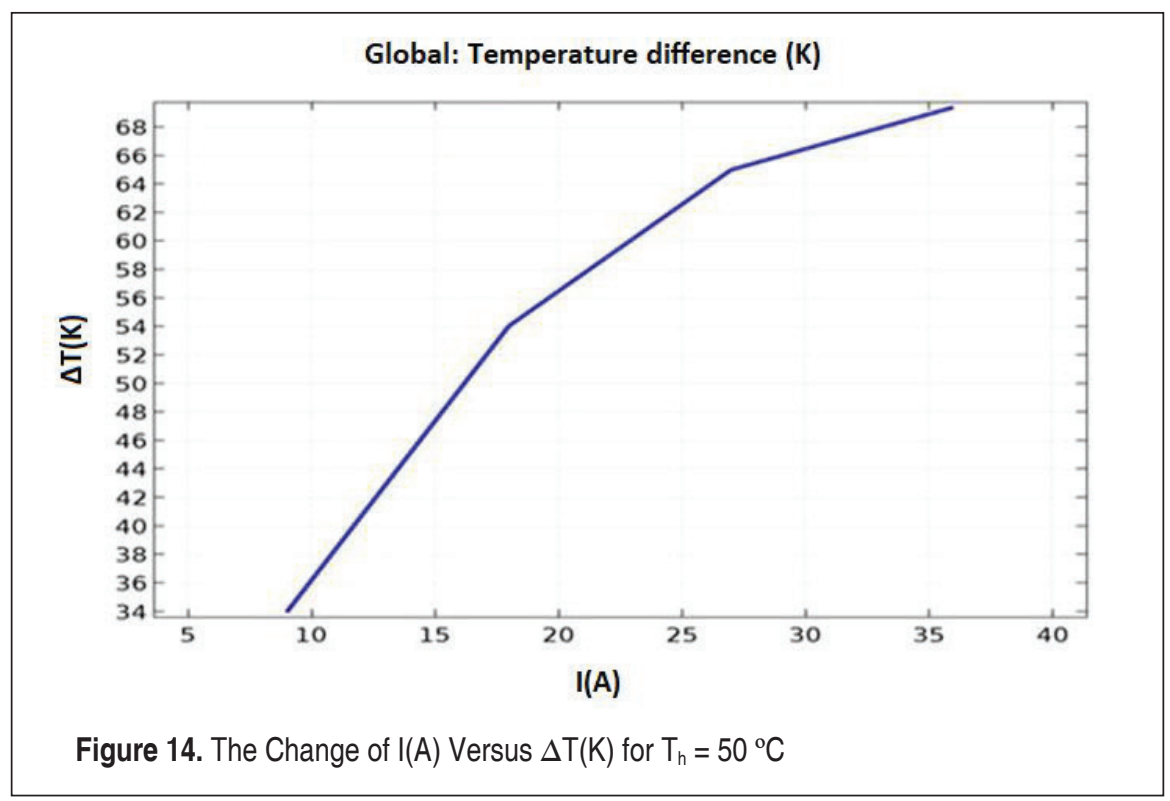

The change of $\mathrm{I}(\mathrm{A})$ according to $\Delta \mathrm{T}(\mathrm{K})$ for $\mathrm{Th}=50^{\circ} \mathrm{C}$ is shown in Fig. 14. The change of $\mathrm{Q}(\mathrm{W})$ according to $\Delta \mathrm{T}(\mathrm{K})$ for $\mathrm{Th}=50^{\circ} \mathrm{C}$ is demonstrated in Fig. 15. The change of I/Imax according to COP for $\mathrm{Th}=50^{\circ} \mathrm{C}$ has been shown in Fig. 16.

The temperature difference of the thermoelectric cooler has increased as the current has increased. The change of $\mathrm{I}(\mathrm{A})$ versus $\Delta \mathrm{T}(\mathrm{K})$ for $\mathrm{Th}=50^{\circ} \mathrm{C}$ is illustrated in Fig. 14.

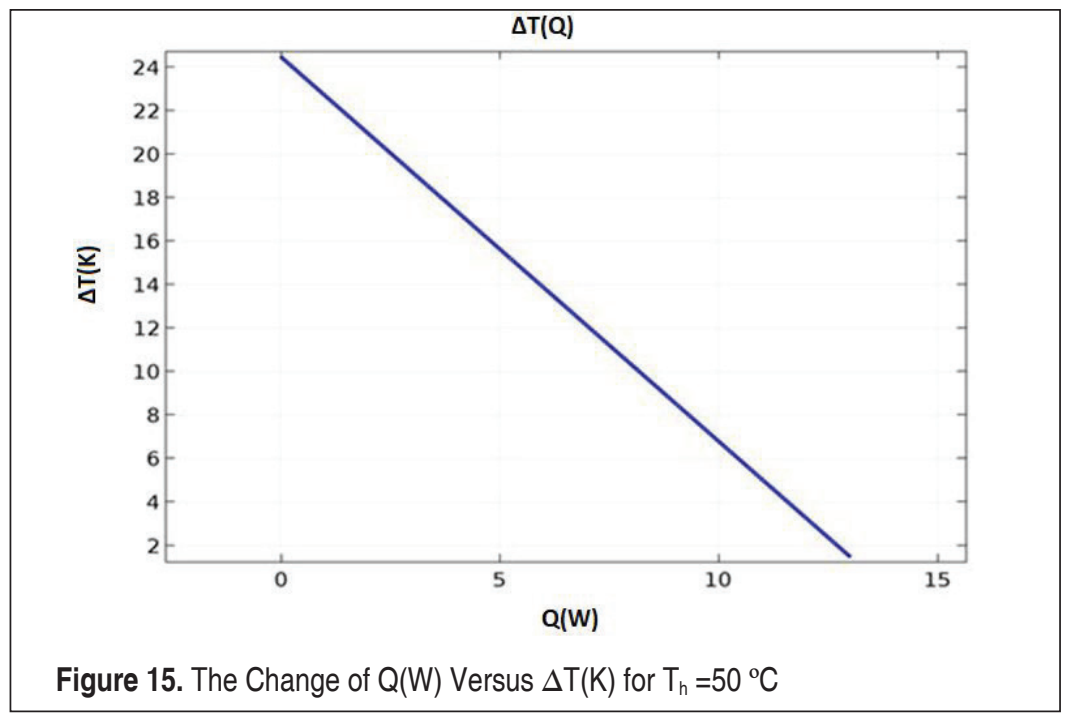




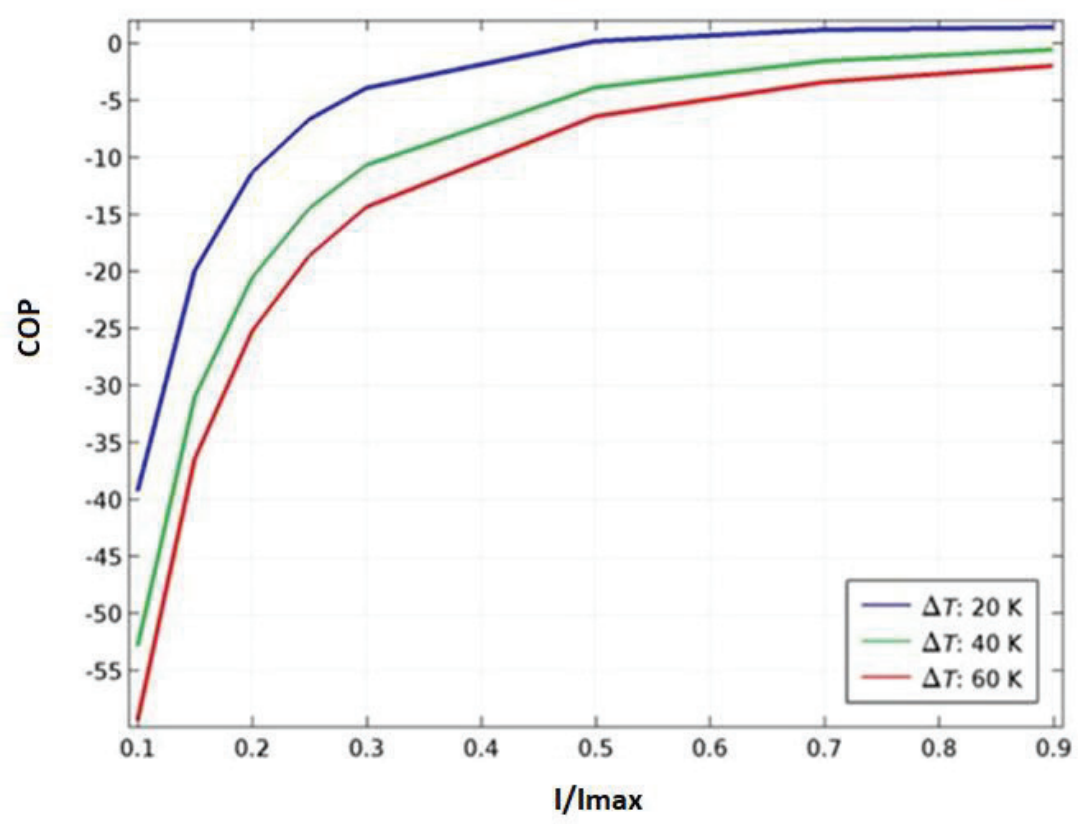

Figure 16. The Change of $\mathrm{I} / \mathrm{Imax}$ Versus COP for $\mathrm{T}_{\mathrm{h}}=50^{\circ} \mathrm{C}$

The temperature difference of the thermoelectric cooler has reduced as the cooling load has increased. The change of cooling load versus $\Delta \mathrm{T}(\mathrm{K})$ for $\mathrm{T}_{\mathrm{h}}=50^{\circ} \mathrm{C}$ is illustrated in Fig. 15.

For temperature differences between ceramics plates of $20 \mathrm{~K}, 40 \mathrm{~K}$, and $60 \mathrm{~K}$, the change of COP versus the relative applied current I/Imax, from 0.1 to 0.9 , is depicted in Fig. 16.

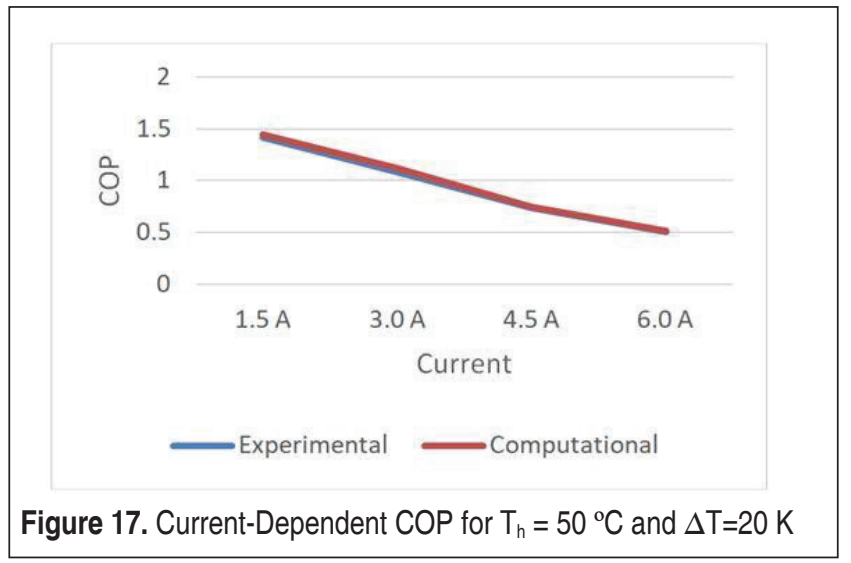




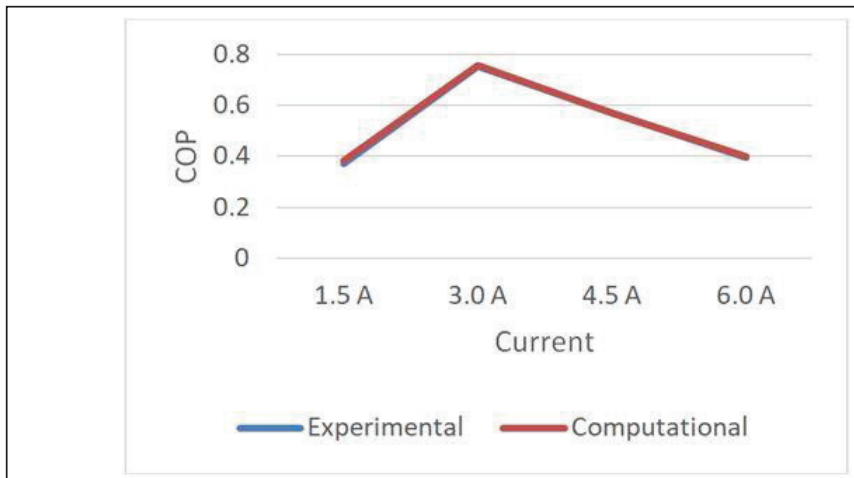

Figure 18. Current-Dependent COP for $T_{h}=50^{\circ} \mathrm{C}$ and $\Delta T=30 \mathrm{~K}$

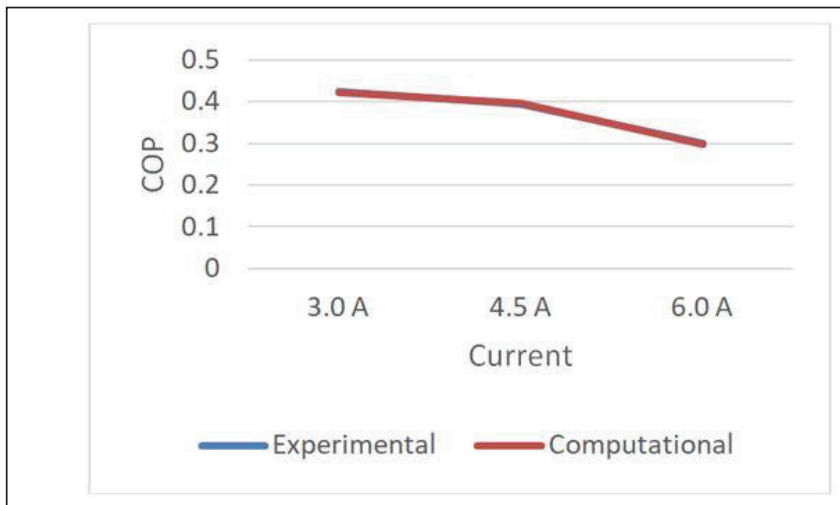

Figure 19. Current-Dependent COP for $T_{h}=50^{\circ} \mathrm{C}$ and $\Delta T=40 \mathrm{~K}$

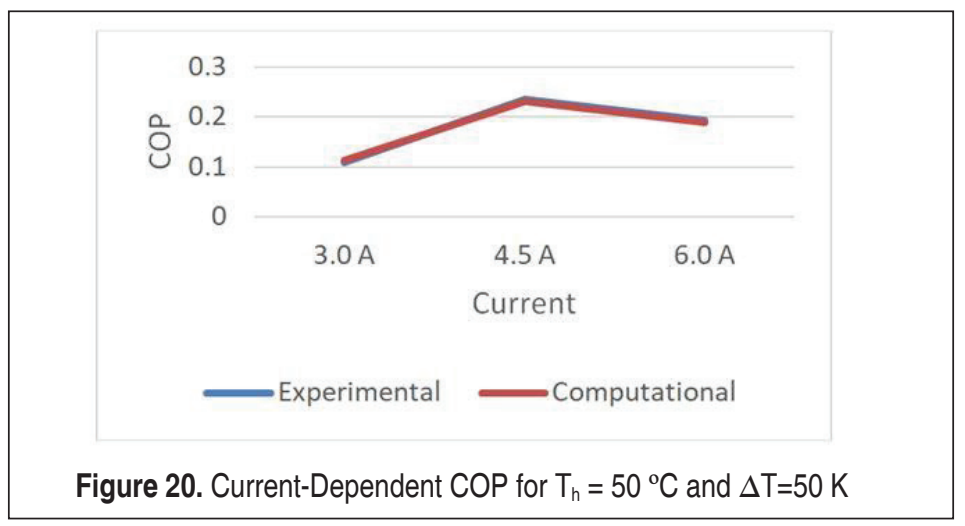


In Fig. 17, Fig. 18, Fig. 19. 20; $\mathrm{T}_{\mathrm{h}}=50^{\circ} \mathrm{C}$; COP coefficients at different currents for each $\Delta \mathrm{T}$ value are given both experimentally and numerically. The reason for the uncertainties in the calculated values is the $\pm 1 \mathrm{C}$ margin of error of the E-type thermocouple used.

Looking at the graphs obtained, it can be said that experimental and numerical results confirm each other.

\section{CONCLUSION}

In this study, thermoelectric refrigerators used in different sectors have been studied. The thermoelectric cooling module with $40 \mathrm{~mm}$ x $40 \mathrm{~mm} \times 3.6 \mathrm{~mm}$ dimensions is used, which works with the Peltier effect principle; a prototype cooling system is designed. This design has been put into production to perform experimental studies and modeling for numerical analysis. The data obtained from the analyses have been compared with the experimental results and found to agree with each other. For the surface temperatures of $25^{\circ} \mathrm{C}$ and $50{ }^{\circ} \mathrm{C}$, the maximum coefficients of performance have been computed to be 1.091 and 1.445 , respectively.

In general, as the temperature of hot surfaces has increased for the same temperature differences, the COP of the thermoelectric cooler has increased.

Although the coefficients of thermoelectric coolers' performance are low, due to their quiet operation, simple installation, and reliability, they are widely used in low current areas. In future studies, it will be investigated how to improve the COP of thermoelectric coolers.

\section{REFERENCES}

1. Riffat S.B., Ma X., Wilson R. 2006. "Performance simulation and experimental testing of a novel thermoelectric heat pump system", Applied Thermal Engineering, Vol:26, 494-501.

2. Riffat S.B., Ma X. 2003. "Thermoelectrics: a review of present and potential applications", Applied Thermal Engineering, Vol:23, 913-935.

3. Rowe D.M. 1995. "CRC handbook of thermoelectrics", Application of thermoelectric cooling, 617-683.

4. Nassar M., Hegazi A. Mousa M. 2019. "Combined effect of pulsating flow and magnetic field on thermoelectric cooler performance", Case Studies in Thermal Engineering, Vol:13, 100-103.

5. Lin Z., Hongbo T., Jianlin Y. 2013. "Analysis of optimal heat exchanger size of a thermoelectric cooler for electronic cooling applications", Energy Conversion and Management, Vol:76, 685-690.

6. Tan S.O., Demirel H. 2015. "Performance and cooling efficiency of thermoelectric mo- 
dules on server central processing unit and Northbridge", Computers and Electrical Engineering, Vol:46, 46-55.

7. Gao M., Rowe D. 1999. "Cooling performance of the integrated thermoelectric micro cooler, Solid-State Electronics”, Vol:43, 923-929.

8. Gökçek M., Sahin F. 2017. "Experimental performance investigation of mini channel water cooled-thermoelectric refrigerator", Case Studies in Thermal Engineering, Vol:10, $54-62$

9. Tan G., Zhao D. 2015. "Study of a thermoelectric space cooling system integrated with phase change material", Applied Thermal Engineering, Vol:86, 187-198.

10. Xu X., Dessel S.V., Messac A. 2007. "Study of the performance of thermoelectric modules for use in active building envelopes", Building and Environment Journal, Vol:3, $1489-1502$.

11. Chinguwa S., Musora C., Mushiri T. 2018. "The design of portable automobile refrigerator powered by exhaust heat using thermoelectric", 15th Global Conference on Sustainable Manufacturing, Procedia Manufacturing, Vol:21, 741-748.

12. Huang B.J., Chin C.J., Duang C.L. 2000. "A design method of a thermoelectric cooler, International Journal of Refrigeration”, Vol:23, 208-218.

13. Karimi G., Culham J.R., Kazerouni V. 2011. "Performance analysis of multi-stage thermoelectric coolers", International Journal of Refrigeration, Vol:34, 2129-2135.

14. Nagy M.J., Buist R.J. 1994. "Effect of heat sink design on thermoelectric cooling performance", AIP Conference Proceedings, 147-149.

15. Gill P., Murray W., Saunders M. 2002. "SNOPT: An SQP Algorithm for large-scale constrained optimization”, SIAM Review, Vol:12, No:4, 979-1006. 